\title{
Infrastructural Investment and Industrial growth: A Private Investment Led Approach
}

\author{
Shobande, A. Olatunji ${ }^{1}$ and Etukomeni C. Charles ${ }^{2}$
}

\begin{abstract}
Industrial development has been upheld as a catalyst for quick recovery of lost fortune in a relegated economy. Spurring industrial development is a function of wide range of actions and activities that must be coordinated within the socio-political and economic enclaves towards the achievement of effective industrialization of the system. Part of the activities required spurring industrialization and economic recovery include conscious investment in infrastructural development. This study examines the impact of infrastructural investment on industrial growth in Nigeria, using the annual time series data sourced from the Central Bank of Nigeria's (CBN) statistical bulletin between 1960 and 2015. The study adopts Autoregressive Distributed Lag (ARDL) bound testing approach developed by Pesaran, Shin and Smith (2001) in estimating the relevant relationships. The result of the long run estimates indicates that the variables are mutually co-integarted, suggesting that a long run relationship exists. The result of the short run dynamics shows that changes in the previous one lag period of infrastructural growth, industrial growth, labor growth, will trigger a $1 \%$ increase in the current industrial output growth. The lag of the error Correction Term which indicates the speed of adjustment of these variables to equilibrium was found to be statistically significant at $1 \%$ with the coefficient value (0.3902). This implies that $39 \%$ of the distortion in the short run is correct on yearly basis. We therefore submit that infrastructural investment in the industrial sector is a necessary but not sufficient condition for economic recovery if structural transformation does not consider the interlink among other important sectors of the economy that would facilitate growth recovery and speed up the rate of industrialization in Nigeria.
\end{abstract}

Keywords: Infrastructural, Industrial, Growth

https://dx.doi.org/10.4314/ejeb.v6i2.2

\footnotetext{
${ }^{1}$ Department of Economics, Faculty of Social Sciences University of Lagos, Email: olatunji.shobande@yahoo.com

${ }^{2}$ Department of Economics, Faculty of Social Sciences University of Lagos, Email: charlesetukomeni@yahoo.com
} 
Infrastructural Investment and Industrial growth

\section{Introduction}

Considerable amount of controversy exists on the extent to which infrastructural investment can possibly influence or predict the future of industrial development in developing countries. In this vein, the point has been argued in majority literature that dearth of physical infrastructure has been one of the major constraints confronting long-term industrial development in Nigeria. It is no longer news that the country has over the past two decades suffered from supply shortages in the areas of energy, transport and telecommunication networks, water resources and Port infrastructure among others. Consequently, poor performance and inefficiency in the operation of the nation's infrastructure, characterized by frequent disruptions in power and water supply, and also the inefficient telecommunication and transportation systems have been described as major constraints on industrial performance and productivity growth in the economy. Anyanwu (2000) acknowledged that the huge cost of doing business in Nigeria has been traced to the lack of infrastructural facilities and loss of competitive product, due to increase in overhead cost resulting in inefficient utilization of existing resources. This argument is thus consistent with the World Bank (1994) finding, which pointed out that a 1 per cent increase in the stock of infrastructure could be associated with a 1 per cent expansion in the Gross Domestic Product (GDP).

In Nigeria, an account of the trend in industrial growth clearly shows that the contribution of the manufacturing sector was only $3.8 \%$ in 1960. This rose to $5.38 \%$ in 1966 and to $6.35 \%$ in 1969 . On the average, the sub sector was responsible for about 5\% of the country's GDP during the 1960s. During the early part of the 1970s, there was decline in the share of manufacturing as its share dropped from $6.35 \%$ in 1969 to $3.6 \%$ in 1970 and to $3.33 \%$ in 1974. However, the contributions of the subsector in the latter part of the decade improved as the share of the subsector in the industrial growth equation stood at $8.79 \%$ in 1979 . The average contribution of the subsector which stood at $4.8 \%$ in the 1970s was slightly lower than its corresponding average in the previous decade (Shobande, 2017). In the 1980s, the rising trend in the latter part of the 1970s was sustained especially in the early 1980s. It is noteworthy that the manufacturing subsector attained its historic peak contribution of $9.9 \%$ during this decade, precisely in 1983. After 1983, its contributions fluctuated between $5.29 \%$ and $8.74 \%$. The average annual contribution of the manufacturing subsector in the 1980s (8.19\%) doubled its corresponding figure in the 1970s. The 1990s was characterized by a fall in the contributions of the subsector. Specifically, the contribution ranged between $5.54 \%$ in 1990 and 
Infrastructural Investment and Industrial growth

$4.89 \%$ in 1999 . Overall, the average share for the decade was $5 \%$ in the 1990 s. In 2000-04, the share of manufacturing was at its lowest ebb of $4.12 \%$ (Shobande, 2017).

The paper sets out to investigate the impact of infrastructural investment on industrial development; specifically, it queries whether infrastructural investment and industrial development matter for long term growth in Nigeria? As it were, the gap this paper is interested in filling is divided into three parts: first provide an overview on the debate and controversy on industrial policy, identify area of consensus, as well as the trade-off in policy; the second area raised important questions on the current state of industrial sub-sectors and their challenges as well as structural problems both within the private sector and government institutions. The third is a cognitive insight on the econometric analysis of related literature, whose empirical evidence and policy guide for future growth has been vehemently debated (Aiginger, 2007).

While, a review of existing literature shows that majority of the studies that had been conducted in the past focused mainly on cross countries analysis, on how infrastructural financing affects economic growth. This does not reflect the current state of infrastructural financing in Nigeria. This study charts a different path as it beams searchlight on the state of infrastructural financing in Nigeria and its implication on industrial development. As a consequence, this study adds new empirical evidence to the existing knowledge by using the advanced econometric techniques of bound testing approach to ARDL to estimate the datasets and prescribe appropriate policy strategies that will further enhance industrial growth in Nigeria.

The next section of our paper critically reviews the literature, followed by the methodology, while subsequent sections contain empirical results and discussion. The final section concludes and makes relevant policy prescriptions and developmental strategies.

\section{Literature Review}

Infrastructure is often regarded as the capacity to promote industrial growth in recent times. This is not farfetched, since it is widely accepted that development cannot occur with growth alone, without structural transformation (IFC, 2012). In the same vein, industrial progress is meaningless without structural change through appropriate infrastructural financing. In terms of definition, infrastructure could be defined as investment in key sectors of the 
economy through access to power, water network, gas, transportation and appropriate telecommunication system, as well as real estate, which has the capacity to improve the quality of life, provide reasonable employment, and reasonably affect the educational system, coupled with bridging the gap between the rural-urban differentials (World bank, 2010). According to IFC (2011), infrastructural financing acts as a catalyst for industrial development through growth related jobs, which can be direct or indirect. In terms of direct growth related jobs, construction of bridges, roads, power network, and related activities provide empowerment for poverty reduction and enhanced productivity for family income and industrial growth. In terms of indirect growth related jobs, the same infrastructure that have been constructed have the potential of creating additional employment for operation and maintenance purposes. Clearly, the private sector through Public Private Partnerships (PPPs) can help to provide technological transformation that will increase the potential of their businesses as well as enhancing industrial growth (IFC, 2011). This approach has once been criticized with reservation, first, higher private investment on infrastructure is associated with better industrial growth, but experience has shown that cost consideration and negotiation by the private sector is critical to future government revenue since a huge amount of money is involved in most of these infrastructural projects (IFC, 2012).

The manufacturing sector has its peculiarities, which has influenced its classification under the industrial sector of the economy. At the basic level, the sector deals with the production of consumer goods, intermediate or producer goods from raw materials. The sector helps in the diversification of the economy, as well as creation of employment and job opportunities. This is however dependent on the effective utilization of other components of the industrial sector as argued by Kaldor (1967). Research and studies have shown that manufacturers in Nigeria are always burdened with high expenses on energy resources because the Nigerian economy is subject to oil price fluctuation, as well as oil production regulation (Onayemi, 2007).

In terms of industrial policies, attempts have been made by successive governments to speed up the rate of industrial growth through the engagement of the private sector to spur investments and contributions in this direction. This has resulted in the adoption of the PPP model across different sub-sectors with the capacity to propel real industrial growth. To this end, privatization policy which seeks to reverse the massive grip of government on economic activities has been introduced and implemented. This policy has been wide spread since the 1980s and has reached advanced level in recent years. So far, over 100 State-Owned Enterprises (SOEs) have been privatized or 
Infrastructural Investment and Industrial growth

concessioned with privatization proceeds exceeding US\$3billion (OkonjoIweala, 2007). Most of the privatized firms have been taken over by foreign firms. A couple of productive sector privatization also yielded some positive economic stories about employment increase and income growth especially in the cement and sugar sub-sectors. One area where multinationals have participated in is the power sector, especially at the generation level, where government has evolved the PPP. Foreign firms have mostly bought into this policy and progress seems to have been made so far (Adegboye and Eregha, 2016).

Considering local content requirement, there is the introduction/debate around the local content initiative which was an aspect of the national industrial policy to allow Nigeria develop vertically integrated production structures by building up domestic manufacturers supply capacity. However, there has been considerable doubt about the effectiveness of this initiative since local input has not been found to be more cost-effective. A tax credit of $20 \%$ is granted for five years to industries that attain the minimum level of local raw material sourcing and utilization. The minimum levels of local raw materials sourcing and utilization by sectors are Agro-allied-70\%; Engineering-60\%; Chemicals$60 \%$ and Petrochemicals-70\% (Tumala et al, 2011). This seems to be one area where the industrial policy has effectively utilized the economic advantage in the country to direct multinational corporations' activities in the country (Adegboye and Eregha, 2016).

In literature, economic theories have identified the transmission mechanisms through which infrastructural investment can positively impact on industrial progress of many developing countries. Development economists posit that at the early stages of economic growth and development, government investment as a proportion of total investment of the economy is high (Musgrave, 1969). Government provides infrastructure, which include: transportation system-road and railway; sanitation system; law and order; health; and education (human capital development), etc. the whole essence of government expenditure during this period is to stimulate the economy for eventual take-off into the middle of economic development. In addition, Wagner's law explains economic growth relative to the size of government. It states that as the per capita incomes in an economy grow, the relative size of the public sector grows. The law argues that as real incomes in the economy increase, government spending in the infrastructure, recreation and culture, roads, welfare, education and health increases (Obiechina, 2010).

EJBE Vol. 6 No. 2/2016 
Furthermore, development economics portend that when government revenue is properly invested in infrastructure, it leads to economic growth. It has also shown that public sector borrowing to finance improvements in infrastructure has positive impact on private sector investments in the economy through increased productivity of labour and greater efficiency of investment, hence, higher levels of aggregate output (Obiechina, 2010). According to Rubinson (1977), larger government revenue in Gross National Product (GNP) enhances economic growth mostly in poorer developing countries. Some studies such as Hemming (1991), Ilori (2002), Akpan (1999), Blejer and Khan (1984), Alogoskoufis and Kalyvitis (1996) revealed that growth in infrastructure capacity is directly correlated with real positive economic growth. Hemming (1991) observed that growth is influenced by the composition of expenditure, since certain types of spending may have more of a growth orientation. Critical among these types of spending are provision of socio-economic infrastructure, operations and maintenance, general administrative and legal framework. Ilori (2002) indicated that a per cent increase in the stock of infrastructure is associated with a positive percentage increase in GDP. Akpan (1999) revealed that public expenditure on transport, communication and agriculture crowd-in private investment, while public spending on manufacturing and construction crowd-out private investment. He pointed that expenditures on education and health have a positive influence on private sector investment. Blejer and Khan (1984) explained that public investment, which has some bearing on infrastructure and provision of public goods, can be complementary to private sector investment. The study observed for a group of developing countries that longer-term infrastructural expenditures, rather than short-term public investment, positively induce private investment. Alogoskoufis and Kalyvitis (1996) examined the effects of infrastructure on output and highlight the production-enhancing role of public investment. Their analysis revealed that public infrastructure changes operate through firms' production function and are then reflected in output changes.

Empirically, several studies like Ukaegbu (1998), Anyanwu (2000), Adenikiju and Chete (2002), Dipak and Ata (2003), Manufacturers Association of Nigeria (2006), Adegbemi, Onakoya and Fasanya (2012) investigated the performance of the manufacturing sector in the Nigerian economy, and revealed that its effect has been negative or insignificant. Adekinju and Chete (2002) in their study of the performance of the Nigerian manufacturing sector revealed that between 1970 and 1980 the sector's performance was satisfactory, but there was a decline in the 1980s as a result of the collapse of oil price in the industrial market. Ukaegbu (1998) and Anyanwu (2000) in their various 
studies revealed that between 1980 and 1989, the manufacturing sector was negatively trending downwards. This is consistent with the study of Dipak and Ata (2003) which opined that the resultant trade restriction due to the oil price crisis, was the reason for the negative trend and decline in the growth rate of the manufacturing sector, as well as output reduction by $25 \%$ between 1982 1986 , thus a reduction in the contribution of the manufacturing sector to its share of total GDP. In the celebrated works of Adegebmi, Onakoya and Fasanya (2012) on the impact of trade openness and the manufacturing sector in Nigeria, they noted that there was a significant payoff from the theory of liberalization, but that inflation rate and exchange rate had a negative influence on the manufacturing sector's performance, due to trade liberalization.

Alli (2008) surveyed the results of a study conducted in 2007 by MAN. His documentation revealed that over the years, the manufacturing sector performed poorly and only $10 \%$ of companies are operating at a sustainable level, while $60 \%$ are likely to shut down or have already shut down due to financial crisis or other forms of crisis. The study by CBN (2008) is consistent with the earlier study of Enebong (2003) who envisaged that the contribution of the manufacturing sector to the share of total GDP will continue to decline because there is the ever increasing problem of inability to access raw materials due to competition by foreign firms. He attributed this to the many policies implemented by the government in the late 1990s, which still poses a huge barrier against the growth of the sector. According to CBN (2008), the contribution of the manufacturing sector to the Nigerian economy is insignificant, compared to the oil and agricultural sub-sectors. Against this backdrop, the $\mathrm{CBN}$ formulated strategies with the singular motive of stimulating industrial production, improving efficiency in industrial production, as well as the enhancement of capacity utilization. However, the effect of these strategies is yet to be felt.

In terms of the energy sector, electricity production and distribution plays a huge role in the development of the Nigerian economy. Electricity is an important factor in economic growth, and this is no fallacy because various sectors of the economy require electricity to function, thus energy consumption is seen as a stimulus to economic growth. Several studies have investigated the role which investment in energy infrastructure plays in the fostering of economic growth. An example of such studies includes the celebrated works of Omisakin (2008) who examined the relationship between electricity consumption and economic growth in Nigeria, from 1970 to 2005, using the bounds testing co-integration approach. The study revealed that electricity 
consumption impacts on the GDP. Also, Gbadebo and Okonkwo (2009) using the co-integration approach in their study of the impact of energy infrastructure on economic growth in Nigeria between 1970 and 2005, documented that there exists a positive relationship between current period energy consumption and economic growth. The result of the study is consistent with Douglason G Omotor (2008) who opined that electricity consumption granger causes GDP, using the johansen co-integration technique and granger causality approach. Yusuf Umar and YahyaZakari (2011) studied the relationship between energy infrastructure and economic growth in Nigeria, using the Auto Regressive distributed lag (ARDL) bounds testing procedure as well as time series data from 1980 to 2010. The study revealed that petroleum consumption, coal consumption and electricity consumption all have long run relationship with economic growth. In the work of Orhewere and Machame (2011) using the Vector error correction model and based granger causality test with data from 1970 to 2005, discovered that electricity consumption effects GDP, both in the short run and long run. The result of the study by Orhewere and Machame (2011) is consistent with that of Umar and Zakari (2009), which documented using the ARDL bound testing procedure and data from 1980 to 2008, that electricity consumption causes GDP. In Taiwan, Chiou-Wei et al (2008) investigated the relationship between energy consumption and economic growth using time series data from 1971 to 2011. Their study revealed that causality does not run from electricity consumption to economic growth. Rising from the above review is the need to further increase investment in infrastructure in the energy sector, as its relationship with economic growth has been clearly defined.

In terms of water infrastructure, United Nations (2010) millennium development goals reported that $14 \%$ of the rural urban population in subSaharan Africa lacks access to clean drinkable water. They further acknowledged that improved sanitation for the same environment shows that $24 \%$ of infrastructural facilities are available. This notion is consistent with the World Health Organization (2002) submission which earlier estimated water related diseases and accounts for $4-8 \%$ in developing countries. Clearly, one way of mending the infrastructural gap is putting in place public spending in this identified area. While many issues surrounding water related infrastructure are widely acknowledged, uncountable reforms to salvage the situation in form of intervention still proved ineffective, since infrastructural deficit still remains a big issue particularly in developing countries (Cutler and Miller, 2005; Mosert, 2006). In terms of empirical studies, efforts have been made to find the link between infrastructural deficit and the quest for industrial development. 
Infrastructural Investment and Industrial growth

For instance Gasana et al (2002), Van Koppen (2003), Mwendera (2006), Batterman et al (2009), Manase et al (2009), United Nations (2010) and Bolaane and Ikgopoleng (2011), , , , acknowledged that an improved water and sanitation infrastructure through appropriate financing have severe implication on the reduction in spread of diseases as well as enhanced industrial development. Batterman et al (2009) also argued that inadequate water infrastructure is a major challenge facing majority of developing countries and providing this key infrastructure will not only reduce the rate of diseases in the sub-Saharan Africa, but also foster development. Bolaane and Ikgopoleng (2011) in their study of the relationship between water infrastructure and economic accessibility in Botswanna, documented that there is need for adequate water facilities to protect human health, enhance environment and improve cultural values. In Rwanda, Gasana et al (2002) shows that the major cause of malaria, measles, malnutrition and acute diarrhea is lack of access to clean water infrastructure. This assertion is consistent with Mwendera (2006) who examined the effect of infrastructure on water related diseases in rural Swaziland. Mwendera (2006) also noted that there is the need for the government of Swaziland to recognize the need to build more infrastructure through appropriate financing, as well as maintenance of the existing supply and sanitation system. Manase et al (2009) studied how communities with high Human Immunodeficiency Virus (HIV) rates benefited from water and sanitation infrastructure in rural South Africa, and concluded that appropriate financing of water infrastructure has technically reduced the rate of spread of HIV diseases in the country. This is consistent with the United Nations' campaign for water infrastructural development, which had the expectation that the proportion of people without access to clean drinking water should reduce by 2015 (United Nations, 2010). Unfortunately, the situation became worse, as more governments of countries have failed to invest in water infrastructure.

In terms of the empirical analysis based on telecommunication infrastructure, mixed reviews have been found. Some studies documented a positive relation relationship between telecommunication infrastructure and growth, while others revealed that the relationship was negative, as well as inconclusive. The following are a few of such studies: Hardy (1980), Ashauer (1989), Norton (1992), Roller and Waverman (2001), Yilmaz et al (2001), Pohjola (2001), Datta A and Agarwal (2004), Ding and Haymes (2004), World Bank report (2006), Tella et al (2007) and Osotimehin et al (2010). Hardy (1980) in his study of the impact of telecommunication on economic growth, using data from both developed and developing countries, revealed that telephones per capita had a significant effect on GDP. This is consistent with Ashauer (1989) 
Infrastructural Investment and Industrial growth

who also found a positive and significant relationship between economic infrastructure and economic growth. Though his estimation technique and methodology was criticized on the grounds that they were inappropriate, he was of the opinion that public expenditure is very productive, and that investment in physical infrastructure will significantly impact on economic growth. Norton (1992) in his study of 47 countries, with panel data analysis from 1957 to 1977, revealed that there is a positive and significant relationship between telecommunication and economic growth. Roller and Waverman (2001) in their study of OECD countries had the same documentation as Norton (1992), that there is a positive and significant relationship between telecommunication infrastructure and economic growth. In the United States of America, Yilmaz et al (2001) examined the impact of telecommunication infrastructure on economic growth in the aggregate and sectorial levels of the economy. Their study revealed that telecommunication infrastructure is a stimulant for growth at the regional level, as it improves the overall productive capacity of the sectors. Pohjola (2001) investigated the relationship between telecommunication infrastructure and economic growth in 39 countries, using panel data from 1990 to 1995 . His study revealed that there is an $80 \%$ gross return on investment in IT for OECD countries, however the return for developing countries was not significant. Also based on a study of OECD countries, Datta A and Agarwal (2004) using the dynamic panel data methodology revealed that telecommunication infrastructure is positively and significantly related to economic growth. In China, Ding and Haynes (2004) in their study of 29 regions revealed that there is a positive correlation and a statistically significant relationship between telecommunication and economic growth (proxied by real GDP per capita). According to World Bank (2006), improvements in a nation's information communication technologies infrastructure, would evidently lead to economic development, and would further lead to a diversified development across all other sectors of the economy if channeled properly. In the celebrated works of Tella et al (2007) which investigated the effect of telecommunications infrastructure on economic growth, they revealed that landline and cell phone penetration significantly affected on economic growth. This is consistent with Osotimehin et al (2010) also in Nigeria, which revealed that telecommunications infrastructure has a significant impact on economic growth, using the Ordinary Least Square estimation technique for the period 1992 to 2007.

In terms of road transport infrastructure, studies like Aschauer (1989c), Fernald (1999), Demetriades and Mamuneas (2000), Calderon and Serven (2004), Briceno et al (2004) and Olorunfemi (2008) all found a positive relationship 
between transport infrastructure and economic growth. Aschauer (1989c) investigated the economic contribution of public investment to economic growth in the G7 countries, with the use of panel data from 1966 to 1985 . He documented an output elasticity of 0.34 to 0.73 , using the Cobb-Douglas function, which reveals the importance of public investment in productivity and growth. In USA, Fernald (1999) investigated the relationship between the construction of inter-state highways in 1950s and 1960s, and growth in the 1970s. He revealed that investment in transport is productive, and that the productivity effect of transport to growth is not permanent, rather it is once and for all. Using panel data analysis of 12 OECD countries, Demetriades and Mamuneas (2000) investigated the effect of transport investment on production and demand, and they revealed that transport investment positively affects production and demand in the long run. Calderon and Serven (2004) in their study of developing countries and high income countries reported that 16 out of 17 developing countries experienced a positive impact of transport investment on economic growth, and 21 out of 29 high income countries also experienced a positive impact of transport investment on economic growth. The result of this study is highly consistent with Briceno et al (2004), which carried out a similar review of about 102 papers and arrived at a similar result.

In Nigeria, Olorunfemi (2008) investigated the relationship between infrastructural services and manufacturing output, using the Vector Auto regressive model (VAR) and granger causality test, as well as time series data between 1981 and 2005. The study revealed that transport and electricity services did not granger-cause growth in the manufacturing sector, but there was a positive relationship between governmental capital expenditure and economic growth.

Studies like that of Tatom (1993), Holtz-Eakin (1994), Evans and Karras (1994), and Nurudeen and Usman (2010) documented a negative relationship between transport infrastructure and economic growth. Holtz-Eakin (1994) in his study made a classification of public investment into education, road and highway system, drainage system, public utilities. His study revealed that there is no significant evidence of a positive effect of the road and highway system on growth, whose share in total public spending was 34.5\%. In the USA, Evans and Karras (1994) used panel data from 1970 to 1986, to investigate the effect of public spending on economic growth. Their study revealed a negative effect of public spending on growth, partially due to the insignificant productivity effect of transport. This result is consistent with Tatom (1993) whose study also arrived at the same result of an insignificant productivity effect of 
transport investment. Nurudeen and Usman (2010) investigated the relationship between government expenditure and economic growth in Nigeria, using the error correction method and co-integration approach. It was revealed that government total capital and recurrent expenditure had a negative effect on economic growth, but also the study attested to the fact that an increase in government expenditure on transport and communication contrastively fosters economic growth. This study was however criticized for its lack of ability to explain the condition and behavior of the specified variables. Clearly, all the review above suggests that there is urgent need for further studies in this area.

\section{Methodology}

The theoretical framework of this study is based on the framework of the Solow growth model to examine the role of infrastructural investment on industrial growth in Nigeria. Following Solow (1957), it is assumed that output $(Y)$ depends positively on both capital $(K)$ and labour $(L)$. Thus the production function is stated as:

$$
Y_{t}=K_{t}^{\alpha} A L_{t}^{1-\alpha}
$$

Where; $Y=$ aggregate real output; $K=$ stock of capital; $A=$ level of technology or labour-augmenting technology; $L=$ stock of labour; $\mathrm{AL}=$ effective labour; $0<\alpha<1$ indicate the elasticity of output with respect to capital and labour and $t=$ time. It is also assumed that all the production factors are fully employed while labour and level of technology grows exogenously at rates $n$ and $g$ respectively. The number of effective labour grew at $n+g$ while capital depreciates at a constant rate. We introduced infrastructural investment into the augmented Solow model. The augmented model is stated as:

$$
Y_{t}=K_{t}^{\alpha} I I_{t}^{\beta} A L_{t}^{1-\alpha-\beta}
$$

The II is infrastructure investment which enters the aggregate production function either directly as an additional input or as part of the technological constraint that determines total factor productivity (Romp and de Haan, 2007; Sanchez-Robles, 1998). Romp and de Haan (2007) argued that the manner in which infrastructure is incorporated into the production process will not make any difference provided the production model is estimated via a Cobb-Douglas function. The model [2] is set up in a linear regression form while decomposing infrastructure investment into expenditure on transport and information and communication. The model is stated as:

$$
I Y_{t}=\alpha_{0}+\alpha_{1} K_{t}+\alpha_{2} L_{t}+\alpha_{3} E T_{t}+\alpha_{4} E I C_{t}+\mu_{t}
$$


Where; $I Y=$ industrial output; $K=$ capital; $L=$ labour force; $E T=$ expenditure on transportation; $E I C=$ expenditure on information and communication; $\alpha_{0}, \alpha_{1-4}=$ parameters; $\mu=$ error term. The theoretical expectation of the model expects the slope of all the independent variables to be positive. All the variables are in logarithm form. The data used is mainly secondary, which are sourced from the Central Bank of Nigeria statistical bulletin and World Development Indicators (2016) and the World Bank Indicator database. The period considered is from 1981 to 2015.

The long-run and short-run estimates of the relationship between infrastructural investment and industrial growth were estimated by the ARDL bounds testing approach developed by Pesaran, Shin and Smith (2001). Using this approach, industrial output growth is expressed as a function of the lagged value of itself and the current and the lagged values of the explanatory variables.

$$
\begin{aligned}
& \Delta Y_{t}=a_{0}+\sum_{p=1}^{n} b_{p} \Delta Y_{t-p}+\sum_{p=1}^{n} c_{p} \Delta K_{t-p}+\sum_{p=1}^{n} d_{p} \mathcal{N}_{t-p}+\sum_{p=1}^{n} e_{p} \Delta E T_{t-p}+\sum_{p=1}^{n} f_{p} \Delta E I C_{-p} \\
& +\rho_{1} I Y_{t-1}+\rho_{2} K_{t-1}+\rho_{3} L_{-1 t}+\rho_{4} E T_{t-1}+\rho_{5} E I C_{-1}+\varepsilon_{t}
\end{aligned}
$$

Where; $\Delta$ is the first difference operator; the parameters $\rho_{i}$, where $i=1,2,3$, 4,5 are the respective long run multipliers; the parameters $b, c, d, e, f$ are the short run dynamic coefficients of the underlying ARDL model in the equation; and $\varepsilon_{t}$ denotes the white noise error term. The Bounds cointegration test involves estimating the above equation and restricting the parameters of the lag level variables to zero. Based on this equation, we tested the following null and alternative hypotheses.

Table 1: Variable Description

Variable Measureme

IY Descriptions Industrial nts

ET output Expenditure on transport $\$$ in Billion Source CBN (2015)

$$
\begin{array}{ll}
* \text { in Billion } & \text { CBN } \\
(2015)
\end{array}
$$

Mean 9227.84

$\operatorname{Max}$

Min

Std Expenditure on

EIC inform \&

$\#$ in Billion

CBN communication

(2015)

363.99

13791.

5264.881

2497.85

K Capital $\quad$ in Billion WDI $\begin{array}{lll}\text { L Labour force } & \text { Value in } & \text { WDI } \\ & 000 & \text { (2016) }\end{array}$

Source: Authors' computation (2017) 
The null hypothesis

$\left[H_{0}: \rho_{0}=\rho_{1}=\rho_{2}=\rho_{3}=\rho_{4}=\rho_{5}=0\right]$

$H_{1}:$ not $H_{0}$

indicates no co-integration or level relationship against the alternative hypothesis implies co-integration and level relationship. The F-statistics indicate the existence of co-integrating relationship among the variables. This is tested by the significance of the lag levels of the variables using the F-test. The calculated F-statistic is compared with the two critical values for the upper and lower bounds tabulated by Narayan (2004). If the calculated value is greater than the upper bounds level; it implies long-run relationship; if the value is lesser than the lower bounds value, it means no long-run relationship; and if it is between both upper and lower bounds, the result is inconclusive. The study also conducted diagnostic and stability tests using the serial correlation, normality, functional form and heteroscedasticity tests.

The description of the variables is presented in Table 1. The table also shows the time series properties of the variables within the periods of 1981 to 2015 . The table shows that the mean values of industrial output (IY), expenditure on transport (ET), expenditure on information and telecommunication (EIC), capital $(\mathrm{K})$ and labour force (L) stood at 9227.84, 363.99, 1847.94, 2322.33 and 38938.1 correspondingly. The standard deviation of industrial output (IY), expenditure on transport (ET), expenditure on information and telecommunication (EIC), capital (K) and labour force (L)from their respective long term mean values every year point at 2497.85, 219.91, 2464.26, 4294.97 and 8426.32 respectively. 
Infrastructural Investment and Industrial growth

Table 2: ADF Unit Root Test Results

\begin{tabular}{|c|c|c|c|}
\hline \multirow{2}{*}{ Variables } & \multicolumn{2}{|c|}{ ADF Tau Statistics } & \multirow{2}{*}{$\begin{array}{c}\text { Order of } \\
\text { Integration }\end{array}$} \\
\hline & Intercept & Linear Trend & \\
\hline $\mathbf{K}$ & $\begin{array}{c}-3.7011(0)[- \\
3.5485]^{* *}\end{array}$ & $\begin{array}{c}-4.7458(0)[- \\
3.6463]^{*}\end{array}$ & 0 \\
\hline$\Delta \mathbf{L}$ & $\begin{array}{c}-4.4145(2)[- \\
4.3098]^{*}\end{array}$ & $\begin{array}{l}-4.7678(0) \quad[- \\
4.3240]^{*}\end{array}$ & 1 \\
\hline ET & $\begin{array}{c}-5.3708(0)[- \\
3.6463]^{*}\end{array}$ & $\begin{array}{l}-5.7381(0)[- \\
4.2627]^{*}\end{array}$ & 0 \\
\hline$\Delta \mathrm{EIC}$ & $\begin{array}{c}-3.2036(0)[- \\
2.9540]^{* *}\end{array}$ & $\begin{array}{l}-3.8416(0)[- \\
3.5530]^{*}\end{array}$ & 1 \\
\hline$\Delta \mathbf{I Y}$ & $\frac{-5.4468(0)[-}{36463]^{*}}$ & $\frac{-5.3330(0)[-}{4.6271 *}$ & 1 \\
\hline
\end{tabular}

Note: * significant at 1\%; ** significant at 5\%; *** significant at 10\% Mackinnon critical values and are shown in parenthesis. The lagged numbers shown in brackets are selected using the minimum Schwarz and Akaike Information criteria.

Source: Authors' computation (2017).

\section{Results and Discussion}

\subsection{Unit Root Test Results}

Table 2 presents the results of the time series properties of the variables included in the model. This pre-test was carried out before estimating the longrun and short-run relationship between social infrastructure investment and economic growth in Nigeria between the periods of 1981-2015. The Augmented Dickey Fuller (ADF) unit root test results presented in Table 4.2 indicate that capital $(\mathrm{K})$ and expenditure on transportation (ET) are stationary at levels [I (0)]. However, industrial output (IY), labour force (L) and expenditure on information and technology (EIC) were reported to be stationary at first difference [I (1)]. Thus, these series are non-mean reverting at levels and do not converge to their long-run equilibrium until they are first differenced.

\subsection{Autoregressive Distributed Lag (ARDL) Results}

\subsubsection{ARDL Cointegration Result}

The data series provides evidence for the use of Autoregressive Distributed Lag (ARDL) technique of analysis. As posited by Pesaran et al., (2001), ARDL is more suitable for variables at different order of integration. The Fstatistics estimate for testing the existence of long-run relationship between 
Infrastructural Investment and Industrial growth

infrastructure development and industrial output growth in Nigeria are presented in Table 3. The estimated F-statistics of the normalized equations $\left(\mathrm{F}_{\mathrm{cal}}=11.4478\right)$ is greater than the lower and upper critical bound at $1 \%$ significance level. It implies that the null hypothesis of no long-run relationship is rejected at $1 \%$ significance level. The implication of the above estimation is that expenditure on transport (ET), expenditure on information and communication (EIC), capital (K), labour force (L) and industrial output growth (IY), all have equilibrium condition that keep them together in the long-run.

Table 3: Existence of ARDL cointegration

\begin{tabular}{lcc}
\hline Test Statistic & Value & K \\
\hline F-statistics (IY|ET, EIC, K, L) & 11.4478 & 4 \\
\hline Critical Value Bounds & & \\
\hline Significance & I0 Bound & I1 Bound \\
\hline $10 \%$ & 2.45 & 3.52 \\
$5 \%$ & 2.86 & 4.01 \\
$2.5 \%$ & 3.25 & 4.49 \\
$1 \%$ & 3.74 & 5.06 \\
\hline
\end{tabular}

Source: Authors' computation (2017).

\subsubsection{Results of Long-run Estimates of Infrastructure Investment and Industrial Output Growth using the ARDL Approach}

Table 4 reveals the long-run estimates between infrastructure investment and industrial output growth in Nigeria. The long-run estimates suggested that expenditure on transport, expenditure on information and communication and capital have positive and significant impact on industrial output growth in Nigeria and all these conform to theoretical expectations. In magnitude terms, a $10 \%$ change in expenditure on transport, expenditure on information and communication and capital increase industrial output growth by $8.5 \%, 3.32 \%$ and $1.19 \%$ respectively. All the variables were found to be significant at $5 \%$ significance level. 
Infrastructural Investment and Industrial growth

Table 4: Long-run coefficients [ARDL: 3,4,4,4,4]

Dependent Variable: Industrial Output (IY)

\begin{tabular}{crrrc}
\hline Variables & Coefficient & Std. Error & t-Statistic & Prob. \\
\hline ET & 0.850379 & 0.056198 & 15.131723 & 0.0000 \\
EIC & 0.332418 & 0.095707 & 3.473289 & 0.0104 \\
K & 0.118477 & 0.005592 & 21.185296 & 0.0000 \\
L & -0.433108 & 0.028897 & -14.987817 & 0.0000 \\
C & 2.961513 & 1.018081 & 2.908918 & 0.0227 \\
\hline
\end{tabular}

Source: Authors' computation (2017).

However, the table indicated that labour force has an indirect impact on industrial output growth in Nigeria which does not follow a'priori expectation. Specifically, a 10\%-point increase in labour force deteriorates industrial output growth by $4.33 \%$. This suprising result is consistent with Fadaerke and Bogetic (2006) who found same for South Africa. The table also shows that the indicator was statistically significant at $5 \%$ significance level.

Table 5: Estimated

Error Correction Model using ARDL [ARDL: 3,4,4,4,4]

Dependent Variable: Industrial Output $(\Delta I Y)$

\begin{tabular}{crrrr}
\hline Variables & Coefficient & Std. Error & t-Statistic & Prob. \\
\hline$\Delta(\mathrm{IY}(-1))$ & 2.311669 & 0.399648 & 5.784269 & 0.0007 \\
$\Delta(\mathrm{IY}(-2))$ & 2.453828 & 0.478078 & 5.132693 & 0.0013 \\
$\Delta(\mathrm{ET})$ & 1.941619 & 0.367916 & 5.277339 & 0.0012 \\
$\Delta(\mathrm{ET}(-1))$ & -0.826085 & 0.205462 & -4.020620 & 0.0051 \\
$\Delta(\mathrm{ET}(-2))$ & -0.746495 & 0.160580 & -4.648748 & 0.0023 \\
$\Delta(\mathrm{ET}(-3))$ & -0.155615 & 0.109420 & -1.422179 & 0.1980 \\
$\Delta(\mathrm{EIC})$ & -0.256907 & 0.092830 & -2.767507 & 0.0278 \\
$\Delta(\mathrm{EIC}(-1))$ & -0.579671 & 0.145179 & -3.992790 & 0.0052 \\
$\Delta(\mathrm{EIC}(-2))$ & 1.262543 & 0.234683 & 5.379780 & 0.0010 \\
$\Delta(\mathrm{EIC}(-3))$ & -0.314843 & 0.118780 & -2.650647 & 0.0329 \\
$\Delta(\mathrm{K})$ & 0.069481 & 0.023247 & 2.988746 & 0.0203 \\
$\Delta(\mathrm{K}(-1))$ & -0.133709 & 0.040535 & -3.298635 & 0.0131 \\
$\Delta(\mathrm{K}(-2))$ & -0.086706 & 0.024993 & -3.469248 & 0.0104 \\
$\Delta(\mathrm{K}(-3))$ & -0.094442 & 0.029234 & -3.230506 & 0.0144 \\
$\Delta(\mathrm{L})$ & 1.153241 & 0.596104 & 1.934631 & 0.0943 \\
$\Delta(\mathrm{L}(-1))$ & -1.280364 & 1.654081 & -0.774063 & 0.4642 \\
$\Delta(\mathrm{L}(-2))$ & 7.592060 & 2.312721 & 3.282740 & 0.0134 \\
$\Delta(\mathrm{L}(-3))$ & -5.726080 & 1.494290 & -3.831975 & 0.0064 \\
$\mathrm{ECT}(-1)$ & -0.390148 & 0.057922 & -6.735787 & 0.0003 \\
\hline
\end{tabular}

Source: Authors' computation (2017).

EJBE Vol. 6 No. 2/2016

Page 175 
Infrastructural Investment and Industrial growth

\subsubsection{Error Correction Models using the ARDL Approach}

The short-run dynamic relationship between infrastructure investment and industrial output growth in Nigeria, indicating the second part of the estimated ARDL model, is reported in Table 5. The lag lengths were selected based on Akaike Information Criterion (AIC). The table below reveals the short-run dynamic estimates among variables of interest.

The short-run estimates suggested that the first to first two lags of industrial output growth exact positive and significant impact on the current industrial output growth in Nigeria. Thus, the short-run estimates of the expenditure on transport, information and communication, capital and labour were also shown in the table. The error correction term indicates the speed of adjustment to restore equilibrium in the model. The value is negative and also significant at $1 \%$ significance level. Specifically, the lag of the error correction term (ECT) was found statistically significant at $1 \%$ level with the co-efficient of -0.3902 . This indicates that $39.02 \%$ of the distortion in the short-run is corrected in the first year in attainting equilibrium on the basis of the changes in the expenditure on transport, information and communication, capital and labour in Nigeria.

\subsubsection{Diagnostic Tests}

The estimated ARDL model is tested for heteroscedasticity, serial correlation, functional form misspecification, parameter stability and normality. Table 6 showed the results for the tests.

Table 6: Diagnostic Tests of Selected ARDL Model

\begin{tabular}{|c|c|c|c|c|c|}
\hline \multicolumn{6}{|c|}{ Results } \\
\hline $\begin{array}{l}\text { Serial } \\
{[0.4145]}\end{array}$ & Correlatic & 1.05559 & Normality Test: 0.9 & $37[0.6$ & 77] \\
\hline $\begin{array}{l}\text { Functional } \\
{[0.9878]}\end{array}$ & Form: & 0.0159 & $\begin{array}{l}\text { Heteroskedasticity } \\
{[0.7288]}\end{array}$ & Test: & 0.7386 \\
\hline
\end{tabular}

Source: Authors' computation (2017).

The estimated ARDL model revealed that the model passed the serial correlation, normal test, heteroscedasticity Ramsey RESET tests, that is the error terms are uncorrelated, normally distributed, same variance and the model is not mis-specified. Thus, they were satisfactory for the ARDL model. 
Infrastructural Investment and Industrial growth

\section{Concluding Remarks and Policy Recommendations}

This study has examined the impact of infrastructural investment on industrial growth, between 1981 and 2015. The analysis was carried out using the Autoregressive Distributive Lag Model (ARDL) developed by Peseran et al. (2001). The results of the cointegration test based on bound test result, shows that the variables are mutually cointegrated, which suggests that a long run relationship persists. The result of the short run dynamics shows that a change in the previous on lag period of industrial growth affects the current year industrial output growth. Specifically, the lag of the error correction term (ECT) was found statistically significant at $1 \%$ level with the co-efficient of 0.3902. This indicates that $39.02 \%$ of the distortion in the short-run is corrected in the first year in attainting equilibrium on the basis of the changes in the expenditure on transport, information and communication, capital and labour in Nigeria. Based on the results obtained, the study recommends that policy makers need to speed up infrastructural financing on telecommunication, construction of bridges, roads, power network and storage facilities that will further stimulate the development of the industrial sector. The negative effects of labour force on industrial growth also calls for concerted effort to be intensified in making sure that labour skills are revived and are effectively utilized. 
Infrastructural Investment and Industrial growth

\section{References}

Abidemi C Adegboye and Perekunah B Eregha (2016) Industrial Policy Formulation and Implementation in Nigeria: The Role of Multinational Corporations. Essays in Honour of Michael O Adejugbe, Professor of Industrial Economics. Department of Economics, University of Lagos Press and Bookshop ltd.

Adekinju A and Chete L (2002) "Productivity, market structure and trade liberalization in Nigeria" Economic development department, Nigerian Institute of social and economic research (AERC). Research paper 126; African economic research consortium.

AFDB (2013) African Development Bank Report, Africa Competitiveness Report. Retrieved from http://www.afdb.org.

AFDB (2016) African Development Bank Report "Incubation of Innovations in Renewable Energy. Retrieved from http://www.afdb.org.

Aiginger K (2007) "Industrial Policy: A dying breed or a re-emerging phoenix" Special issue on the future of Industrial Policy, Journal of Industry, Competition and Trade, 7(3-4), 297-323.

Ajakaiye et al (2016) "Understanding the Relationship between Growth and Employment in Nigeria" Africa Growth Initiative, United Nations University, UN-WIDER.

Akpan A H (1999) "Public Expenditure and Economic Growth in a Petroleum Based Economy: Nigeria. SAJEMSNS 2(3).

Alli F (2008) Nigeria: 9 years of manufacturing with tears, - any hope in sight? Vanguard (Lagos) retrieved from http://allafrica.com/stories/200805290133.html?page=2.

Alogoskoufis G and S Kalyvitis (1996) Public Investment and Endogenous Growth in a Small Open Economy" Discussion Paper Series 1479, Center For Economic Research, London.

Anyanwu C M (2002) Productivity in the Nigerian manufacturing industry, Research department; Central Bank of Nigeria, 124-129.

Anyanwu G. A (2000). Graduates transition from study to employment: A study of the arts and agriculture graduates of university of Nigeria in the world of work. Department of Home Science and Nutrition.

Aschauer D (1989) "Genuine Economic Returns to Infrastructure Investment" Policy Studies Journal 21, 380-390.

EJBE Vol. 6 No. 2/2016 
Infrastructural Investment and Industrial growth

Aschauer D (1989). Is Public Expenditure Productive? Journal of Monetary Economics 23, 177-200.

Batterman, S., Eisenberg, J., Hardin, R., Kruk, M., Lemos, M., Michelak, A., Wilson, M. (2009). Sustainable control of water-related infectious diseases: A review and proposal for interdisciplinary health-based systems research. Environmental Health Perspectives, 117(7), 10231032.

Blejer M I and Khan M S (1984) "Government Policy and Private Investment in Developing Countries" IMF Staff Papers, 31, 379-403.

Bolaane, B., \&Ikgopoleng, H. (2011). Towards improved sanitation: Constraints and opportunities in accessing waterborne sewage in major villages of Botswana. Habitat International, 35(3), 486-493.

Briceno-Garmendia C, Estache A and Shafik N (2004) "Infrastructure Services in Developing Countries: Access, Quality, Costs and Policy Reform". Policy Research Working Paper 3468, World Bank, Washington D C.

Calderon C and L Serven (2004). "The Effects of Infrastructure Development on Growth and Income Distribution". Policy Research Working Paper 3400, World Bank.

Chiou-Wei S, Chen C, Zhu Z (2008). Economic growth and Energy consumption: A revisited Evidence from linear and nonlinear Granger causality. Energy Economics, 30, 3063-3076.

Cutler, D.M., Miller, G. (2005). The role of public health improvements in health advances: The twentieth century United States. Demography, 42(1), 1-22.

CBN (2008) Central Bank of Nigeria Statistical Bulletin, CBN Publication.

CBN (2016) Central Bank of Nigeria Statistical Bulletin, CBN Publication

Datta A and Agarwal S (2004) "Telecommunication and Economic Growth: A panel data approach" Applied Economic, 36, 1649-1654.

Demetriades P and Mamuneas T (2000). "Intertemporal Output and Employment Effects of Public Infrastructure Capital: Evidence from 12 OECD Economies". The Economic Journal 110, 687-712.

Ding L and Haymes E K (2004). "Telecommunication Policy" Research Conference, Washington $D C$. 
Infrastructural Investment and Industrial growth

Dipak M and Ata M (2003) "The African manufacturing firm, an analysis based on firm studies in Sub-Saharan Africa, Taylor and Francis Ltd.

Douglason G O (2008). Causality between energy consumption and economic growth in Nigeria. Pakistan Journal of Social Sciences 5(8), 827-825.

Enebong A (2003) Nigeria's imperative in the new world order, Workshop report. African economic research consortium (AERC). Nairobi Kenya and Trade policy research and training. Department of Economics, University of Ibadan, Ibadan.

Evans P and Karras G (1994). Are Government Activities Productive? Evidence from a panel of US states, The Review of Economics and Statistics. 761, 1-11.

Fadderke, J and Bogetic, Z (2006) Infrastruture and Growth in South Africa: Direct and Indirect Labour Productivity Impact of 19 Infrastructure Mesasure. Economic Research Of Southern Africa Working Paper No 9 .

Fasanya and Onakoya A O (2012) Does Foreign Aid Accelerate Economic Growth? An Empirical Analysis for Nigeria. International Journal of Economics and Financial Issues, 4(2), 423-431.

Fernald J G (1999). Roads to Prosperity? Assessing the Link between Public Capital and Productivity. American Economic Review. 89(3), 619638Gasana, J., Morin, J., Ndikuyeze, A., \&Kamoso, P. (2002). Impact of water supply and sanitation on diarrheal morbidity among young children in the socioeconomic and cultural context of Rwanda. Environmental Research, 90(2), 76-88.

Gbadebo O and Okonkwo C (2009)Does energy consumption contribute to economic performance? Empirical evidence from Nigeria. Journal of Economics and Business, 12(2).

Hardy A P (1980). "The Role of the Telephone in Economic Development". Telecommunication Policy, 4, 278-286.

Hemming R (1991) "Public Expenditure, Stabilization and Structural Adjustment" In Public Expenditure Handbook: A Guide to Public Policy in Developing Countries. Keyoyoung Chu and Richard Hemming, (eds) Washington DC. IMF

Hendrik R and Waveman L (2001) "Telecommunications Infrastructure and Economic Development: A Simultaneous Approach. Published by the American Economic Review, 91(4), 278-286.

EJBE Vol. 6 No. 2/2016

Page 180 
Infrastructural Investment and Industrial growth

Holtz-Eakin D (1994). "Public Sector Capital and the Productivity Puzzle" Review of Economics and Statistics 76, 12-21.

IFC (2011) International Finance Corporation, Annual Report

IFC (2012) International Finance Corporation, Infrastructure. Telling our Story, vol 6 IFC.

Ilori B (2002) "The Role of Government in the Development of Basic Infrastructure" paper presented at the Eleventh Annual Conference of thee Zonal Research Units, Research Department, Central Bank of Nigeria.

Kaldor, N. 1967. Strategic Factors in Economic Development. New York: W.F. Humphrey Press.

MAN (2006) Manufacturers Association of Nigeria report, retrieved fromhttp://www.manufacturersnigeria.org/membership.html.

MAN (2007) Manufacturers Association of Nigeria publication, retrieved from http://www.manufacturersnigeria.org/membership.html.

Manase, G., Nkuna, Z., \&Ngorima, E. (2009). Using water and sanitation as an entry point to fight poverty and respond to HIV/ AIDS: The case of Isulabasha Small Medium Enterprise. Physics and Chemistry of the Earth, 34(13-16), 866-873.

MBPN (2015) Ministry of Budget and National Planning: A Transformation Agenda Onayemi T (2007) Nigerian Oil: Prices, politics and the people, published in Nigeria Today 2003, Available from:http://www.nigeriantoday.com/nigeria_oil.htm.

Mostert, E. (2006). Managing water resources infrastructure in the face of different values. Physics and Chemistry of the Earth, 33(1-2), 22-27.

Musgrave R A (1969) The Theory of Public Finance, New york: McGraw Hill Book Coy.

Mwendera, E.J. (2006). Rural water supply and sanitation (RWSS) coverage in Swaziland: Toward achieving millennium development goals. Physics and Chemistry of the Earth, 31(15-16), 681-689.

Norton S (1992) "Transactions Costs Telecommunication and the Microeconomics of Macroeconomic Growth", Economic Day and Cultural Change, 41(6), 175-196. 
Infrastructural Investment and Industrial growth

Nurudeen A and Usman A (2010). Government Expenditure and Economic Growth in Nigeria: A Disaggregated Analysis. Business and Economics Journal 4, 1-11.

Obiechina M E (2010) "Analysis of Revenue Generation as a Tool for SocioEconomic and Infrastructural Development in Nigeria". Bullion, Publication of the Central Bank of Nigeria, 34(4).

Olorunfemi Sola (2008). Infrastructural Services and Manufacturing Growth in Nigeria: A Dynamic Analysis. African Economic and Business Review $6(2)$.

Omisakin O A (2008) Energy consumption and economic growth in Nigeria: A Bounds Testing Approach. Journal of Economic Theory, 2(4), 18-123.

Orhewere B and Machame H (2011). Energy consumption and economic growth in Nigeria. JORIND 1(9), 1596-8308.

Osotimehin K O, Akinkoye E Y and Olasanmi O O (2010). The Effects of Investment in Telecommunications Infrastructure on Economic Growth in Nigeria. Oxford Business and Economics Conference Program, Retrieved from www.gcbe.us/2010_OBEC/data/confcd/index.htm.

Pesaran M H, Shin Y and Smith R J (2001) "Bounds Testing Approaches to the Analysis of Level Relationships" Journal of Applied Econometrics, 16, 289-326.

Pohjola M (2001) Information Technology and Economic Growth: A CrossCountry Analysis. Oxford: Oxford University Press.

Rubison R (1977) "Dependence, Government Revenue and Economic Growth", Studies in Comparative International Development , XII (2): 3-28.

Tatom J A (1991). Public Capital and Private Sector Performance. Federal Reserve Bank of Saint Louis Review, 73, 3-15.

Tella S A ,Amaghionyeodiwe L A and Adesoye B A (2007). Telecommunications Infrastructure and Economic Growth: Evidence from Nigeria. Research paper at UN-IDEP and AFEA joint conference on Sector-led Growth in Africa and Implications for Development, Dakar, Senegal.

Tumala M M, Ajibola O I, Omotosho B.S and Baruwa O A (2011). "Survey of Foreign Assets and Liabilities in Nigeria 2011 Report" CBN Journal of Applied Statistics 3(2).

EJBE Vol. 6 No. 2/2016 
Infrastructural Investment and Industrial growth

Ukaegbu C (1998) Managers and their entrepreneurs: power and authority in indigenous private manufacturing firms in Nigeria. African entrepreneurship: Theory and Reality. Gainesville Florida: University Press of Florida, 181-198.

Umar et al (2009), Energy consumption and economic growth in Nigeria: ARDL Bound Analysis. European Scientific Journal, 7(11).

United Nations. (2010). Goal 7. The Millennium Development Goals Report, 58-65.

Van Koppen, B. (2003). Water reform in sub-Saharan Africa: What is the difference? Physics and Chemistry of the Earth, 28(20- 27), 1047-1053.

WHO (World Health Organization) (2002). Reducing risks, promoting healthy life. The World Health Report 2002. Geneva.

World Bank (1994) World development report: Infrastructure for development.

World Bank (2006). Overview Information and Communications for Development, Global Trends and Policies. The International Bank for Reconstruction and Development/ World Bank.

World Bank (2010) World development report; Africa's Infrastructure: A time for Transformation.

Yumaz S, Hatres K and Dinc M (2001). "The Impact of Telecommunications Infrastructure Investment on Sectorial Growth" Australian Journal of Regional Studies, 7(3), 383-397.

Yusuf D and Yahya Z (2011). Energy consumption- economic growth nexus in Nigeria: An empirical Assessment based on Bound Test Apporach. European Scientific Journal, 8(12). 